\section{Prevalence and determinant factors to lipid abnormalities among HIV-infected patients: a cross- sectional study of 812 patients}

\author{
Prevalência e fatores determinantes das alterações lipídicas em \\ pacientes infectados pelo HIV: um estudo transversal de 812 pacientes
}

Dario J. H. P. Signorini', Michelle C. M. Monteiro², Dario H. Signorini', Walter A. Eyer-Silva'

$\mathrm{W}$ e read with interest Diehl and cols. (1) report on the prevalence of HIV-associated lipodystrophy among 180 patients followed in Londrina (1). We wish to report the results of a large cross-sectional survey on the prevalence and predisposing factors to lipid abnormalities among 812 adult HIV-infected patients followed at our outpatient unit in the city of Rio de Janeiro.

We found that the overall prevalence of lipid abnormality was $64 \%$ (95\% CI, 60\%$67 \%$ ), whereas prevalence estimates of hypercholesterolemia, increased LDL-cholesterol and hypertriglyceridemia were 37\% (95\% CI, 34\%-41\%), 30\% (95\% CI, 27\%-33\%) and $48 \%(95 \% \mathrm{CI}, 44 \%-51 \%)$, respectively. In multivariate analysis, factors associated with presence of lipid abnormality were older age (odds ratio [OR], 1.03; p-value < $0.001)$, being on any antiretroviral regimen $(\mathrm{OR}, 2.07 ; \mathrm{p}<.001)$, and a high CD4+ cell count (OR, 1.63; p .02). The latter association seems to be related to a longer period on antiretroviral therapy. In contrast, sex, schooling, HIV exposition categories, CD8+ cell count and plasma viral load were not significantly associated with lipid abnormalities. The clinical consequences of high serum lipid levels include a higher risk of coronary artery disease. Since many of these patients also present other risk factors such as hypertension, smoking and diabetes mellitus, and display body fat changes of lipodystrophy, all of which are statistically associated with the metabolic syndrome and the risk of coronary artery disease (2), pharmacological and non pharmacological interventions for control of dyslipidemia and hyperglycemia should be aggressively sought. Whenever possible, the use of antiretroviral agents known to have a lower impact on lipid metabolism should be considered.

Disclosure: no potential conflict of interest relevant to this article was reported.

\section{REFERENCES}

1. Diehl LA, Dias JR, Paes AC, Thomazini MC, Garcia LR, Cinagawa E, et al. Prevalence of HIV-associated lipodystrophy in Brazilian outpatients: relation with metabolic syndrome and cardiovascular risk factors. Arq Bras Endocrinol Metabol. 2008;52:658-67.

2. Hadigan C, Meigs JB, Corcoran C, Rietschel P, Piecuch S, Basgoz N, et al. Metabolic abnormalities and cardiovascular disease risk factors in adults with human immunodeficiency virus infection and lipodistrophy. Clin Infect Dis. 2001;32:130-9.
Ambulatório de Imunologia, Hospital Universitário Gaffrée e Guinle, Departamento de Medicina Geral, Universidade Federal do Estado do Rio de Janeiro (UNIRIO), Rio de Janeiro, RJ, Brazil ${ }^{2}$ Ambulatório de Endocrinologia e Metabolismo, Hospital Universitário Gaffrée e Guinle, Departamento de Medicina Geral, UNIRIO, Rio de Janeiro, RJ, Brazil

Correspondence to: Dario J. H. P. Signorini Av. Nossa Senhora de Copacabana 709, sala 1207 - 22050-000 - Rio de Janeiro, RJ, Brazil dariohart@yahoo.com.br

Received on Jan/7/2010 Accepted on May/26/2010 